\title{
Belgeo
}

Revue belge de géographie

\section{Elite sport and the new economic development geographies. Comment on "The paradox of measuring success of nations in elite sports" by Veerle De Bosscher, Bruno Heyndels, Paul De Knop}

\section{Stijn Oosterlynck}

\section{(2) OpenEdition}

\section{Journals}

Electronic version

URL: http://journals.openedition.org/belgeo/10317

DOI: $10.4000 /$ belgeo. 10317

ISSN: 2294-9135

Publisher:

National Committee of Geography of Belgium, Société Royale Belge de Géographie

Printed version

Date of publication: 30 June 2008

Number of pages: $235-238$

ISSN: 1377-2368

Electronic reference

Stijn Oosterlynck, «Elite sport and the new economic development geographies. Comment on "The paradox of measuring success of nations in elite sports" by Veerle De Bosscher, Bruno Heyndels, Paul De Knop », Belgeo [Online], 2 | 2008, Online since 20 October 2013, connection on 22 September 2020. URL : http://journals.openedition.org/belgeo/10317 ; DOI : https://doi.org/10.4000/belgeo.10317

This text was automatically generated on 22 September 2020 .

Belgeo est mis à disposition selon les termes de la licence Creative Commons Attribution 4.0 International. 


\title{
Elite sport and the new economic development geographies. Comment on "The paradox of measuring success of nations in elite sports" by Veerle De Bosscher, Bruno Heyndels, Paul De Knop
}

\author{
Stijn Oosterlynck
}

1 De Bosscher, De Knop, Heyndels and van Bottenburg develop an objective methodology for the measurement of success of nations in elite sport contests. After discussing the merits of absolute and relative measures of success, they argue in favour of the latter because controlling for "exogenous macro-influences" such as GDP per capita, population size and political system allows for an evaluation of the effectiveness of national sport policies. I have no problems with the argument in its own right, neither with the sophisticated statistical apparatus mobilised to support it, but I would like to question the specific economic discourse in which the argument is couched and relate it to recent debates in economic geography about the nature of the "economic" and its spatiality. The authors present Olympic Games as markets for medals, in which fluctuations of demand and supply influence the price of medals ("sport success"). The training system of athletes is likened to a national production complex governed by strategic planning efforts and human capital management and aimed at increasing global market share. Given this discursive representation of elite sports as an economic sector and system of production that needs to be governed by the same kind of strategic planning efforts and economic development strategies as any other economic sector, it seems only fair to put this argument in the context of contemporary debates on the nature of the "economic" in economic geography and planning and development studies. 
2 Jamie Peck recounts how in the early 1970s economic geography gave up its "monogamous relationship with neoclassical economics" and looked elsewhere for intellectual company (Peck, 2004). The "new economic geographies" that resulted from a number of flings with different intellectual traditions have a radically decentred, plural and heterodox understanding of what constitutes the "economic" (Amin and Thrift, 2000; Martin and Sunley, 2001). The neoclassical approach, the language and problem definition of which De Bosscher et al. seem to mobilise to set up their approach to national elite sport success, tends to reduce the economic to competitive, marketmediated relations that are disembedded from their social, cultural and political context. I do not intend here to argue that using a neoclassical conception of the economic is necessarily wrong or illegitimate, but only that it is not self-evident and therefore needs some justification. Are the authors suggesting that the Olympic Games really are markets in the ontological sense and as conceptualised by neoclassical economists? If so, how does that relate to another powerful imaginary of the Olympic Games as an event that brings people together in peace, cooperation and respect for universal moral principles? Or are the authors making the more modest epistemological claim that it is potentially interesting to analyse Olympic Games as if they were markets? The value of this epistemological position than has to be judged against the explanatory value of the arguments about the territorial dynamics of "athlete production systems" that are developed on the basis of it.

3 But even the more modest epistemological position seems open to criticism. High profile sporting events such as the Olympic Games are implicated in and invested with geopolitical strategies. One only need to refer here to the current public debate about China's involvement in the conflict in Sudan and whether or not China, as host of this year's Olympic Games, is violating the Olympic dream of peace and international cooperation or to China's earlier boycott of the Olympic Games because the IOC recognised Taiwan as a separate participating country. The authors are no doubt aware of the geopolitical dynamics surrounding Olympic Games, but choose to externalise it from their explanatory model. This is clear for example from their decision to take the 1988 Olympic Games as the starting point for their analysis because "this was the first games since 1972 that had not been contaminated by some form of boycott". Given that politics has never been external to sporting events, but has always been inherent to it, I would suggest that integrating political dynamics in explanatory models is important to understand national success in elite sports. Conceptualising the Olympic Games as competitive markets for medals ignores the severe political battles about the rules that govern this competition, amongst others about who is to be recognized and allowed in the "market" as competitor.

Highlighting the political dimension of Olympic Games also points to its spatiality. The spatial dimension of the analysis is now restricted to comparing pre-existing national territories. For human geographers, especially since the debate with social theorists about space as a social construct in the early 1980s (Gregory and Urry, 1985; Lefebvre, 1974; Smith, 1984), space is much more than a flat surface partitioned in different nation states. Space is not naturally given, but that which is produced through social, economic and other human activities. Globalisation debates have further problematised conceptions of (national) spaces as naturalised containers for social practices (Brenner et al., 2003). I would like to suggest that the Olympic Games are and have always been integral to the production and reproduction of national or other spaces. Sporting 
success is celebrated as a national victory and is often mobilised by political-economic elites to boost national feelings of pride, unity and cohesion, often in the face of the social divisions that cut through societies. The debate about whether elite sport policies in Belgium should be located on the federal or regional level underscores its political function. To be sure, De Bosscher et al. do acknowledge the importance of politics, but a dummy variable for (former) communist countries seems too limited to capture the many different ways in which global sporting success is implicated in nation-building strategies.

5 All this has implications for the system of production of athletes. Just like any other system of production, disciplining the human bodies in which the labour for production of Olympic medals is embedded is one of the key challenges. This challenge is probably most clearly expressed in the manifold tensions between human athlete bodies as input in the production system for global sporting success on the one hand and their necessarily extra-economic existence as social, political, cultural and moral beings on the other hand. The contracts offered to some athletes that will participate in this year's Olympic Games in China and that ban them from speaking on political issues and the suspension of two Afro-American athletes from the US team in 1968 after they expressed their support for "black power" are only two out of many examples that express the political contradictions that are implied in the production system for athletes and in national sporting policies. In this sense, it looks odd to set "elite sport culture and the tradition of sport and sporting success in a nation" apart as factors that cannot be influenced by government policies, as De Bosscher et al. do. Moreover, following the cultural turn in economic geography, increasing research attention is paid to the crucial role played by cultural factors in underpinning economic development and planning strategies, an insight that I believe merits more attention in the author's assessment of strategic planning efforts in the field of elite sport (Lee and Wills, 1997). This would however require a more qualitative (and probably case study based) understanding of the history and multiple dynamics in sport policies than is offered in this paper.

6 All this is certainly not to deny the value in De Bosscher et al.'s approach to measuring success of countries in elite sport events, which is certainly sophisticated and welldeveloped in its own methodological terms, but to re-ground it in current understandings of spatial economic development strategies in human geography. A large part of this literature has made successful attempts to work with an enriched, territorially grounded and socially and culturally embedded notion of the economic. It seems to me that studies that evaluate the sporting success of nations would benefit from such a broadened conception of the economic and a critical assessment of the nature of sport policies as implied in a production system for athlete labour. 


\section{BIBLIOGRAPHY}

AMIN A. \& THRIFT N. (2000), "What kind of economic theory for what kind of economic geography?, Antipode, 32, pp. 4-9.

BRENNER N., JESSOP B., JONES M. \& MACLEOD G. (2003), "Introduction: state space in question”, in BRENNER N., JESSOP B., JONES M. \& MACLEOD G., (eds.), State/space: a reader, Oxford, Basil Blackwell Publisher, pp. 1-26.

GREGORY D. \& URRY J. (eds.) (1985), Social relations and spatial structures, Houndmills, Macmillan Education Ltd.

LEE R. \& WILLS J. (1997), Geographies of economies, London, Arnold.

LEFEBVRE H. (1974), The production of space.

MARTIN R. \& SUNLEY P. (2001), “ethinking the 'economic' in economic geography: broadening our vision or losing our focus ?”, Antipode, 33, pp. 148-161.

PECK J. (2004), Economic sociologies in space, SECONS Discussion Forum 5, 72.

SMITH N. (1984), Uneven development. Nature, capital and the production of space, Oxford, Basil Blackwell Publisher.

\section{AUTHOR}

\section{STIJN OOSTERLYNCK}

Katholieke Universiteit Leuven, Research Unit Planning and Development, Stijn.Oosterlynck@asro.kuleuven.be 